\title{
SYNCHRONIZATION OF ESTRUS IN BLACK BENGAL DOES
}

\author{
M. A. M. Y. Khandoker ${ }^{1 *}$, A. Sultana ${ }^{1}$, Q. S. Akter ${ }^{1}$, K. M. A. Tareq ${ }^{1}$, M. M. Mia ${ }^{1}$, \\ S. S. Husain ${ }^{1}$ and D. R. Notter ${ }^{2}$
}

\begin{abstract}
The present study was undertaken to measure estrus response (\%), interval to estrus (hr), duration of estrus and conception rate (\%) after synchronization in Black Bengal does. Synchronization of estrus was done by intramuscular injection of synthetic $\mathrm{PGF}_{2 \alpha}$ as dinoprost ${ }^{\circledR}$. Two trials were conducted with twenty cyclic fertile adult Black Bengal does. The age and body weight of the does were between 18 to 21 months and $11-13 \mathrm{~kg}$, respectively. After synchronization all the does were observed closely up to 48 hours to note the estrus behavior. All the signs or behavior of synchronized estrus were recorded in details. Out of 20 does, 19 does showed behavioral signs of heat and expressed estrus behavior after synchronizing with synthetic $\mathrm{PGF}_{2 \alpha}$ as dinoprost ${ }^{\circledR}$ injection. The behavioral estrus was found after 45.5 hours and 45 hours injected with $2 \mathrm{ml}$ and $1 \mathrm{ml}$ dinoprost ${ }^{\circledR}$, respectively. The duration of estrus was recorded 51 hours and 23 hours for does treated with $2 \mathrm{ml}$ and $1 \mathrm{ml}$ dinoprost ${ }^{\circledR}$, respectively. The conception rate was observed $42.86 \%$ and $40.00 \%$ treated with $2 \mathrm{ml}$ and $1 \mathrm{ml}$, respectively. From the result of this study it can be concluded that synchronization of estrus with $1 \mathrm{ml}$ of dinoprost ${ }^{\circledR}$, may be used for inducing estrus of Black Bengal doe under Bangladesh condition.
\end{abstract}

Key words: Black Bengal does, Conception rate, Estrus synchronization

\section{Introduction}

Black Bengal goat is a potential genetic resource in Bangladesh and famous for high fertility, prolificacy, superior quality chevon, best quality skin, early sexual maturity, resistance against common diseases, aseasonality, short kidding interval and very good tropical adaptability (Husain, 1993 and Amin, 2000). In a herd where Artificial Insemination (Al) is to be practiced in does, one of the most important attribute is to detect estrus so that insemination can be performed at the proper time. The traditional system of management practice makes it difficult to implement an Al programmer on the basis of naturally occurring estrus (Lauderdale et al., 1981). Synchronization of estrus may release the problem somewhat, especially with sheep and goat. The use of Al programmer to a large extent depends upon the development of simple, cost effective and efficient system of estrus synchronization programmer (Peters, 1983).

\footnotetext{
* Correspondence author: M. A. M. Y. Khandoker, E-mail: yahiakhabg@yahoo.com

${ }^{1}$ Reproductive Biotechnology Laboratory, Department of Animal Breeding and Genetics

Bangladesh Agricultural University, Mymensingh-2202, Bangladesh

2 Department of Animal and Poultry Sciences, Virginia Polytechnic Institute and State University, Blacksburg, VA 24061-0306, USA
}

(Received: November 04, 2009) 
Estrus induction and mating outside the breeding season could have a great impact on the exploration of animals showing reproductive seasonality. Controlled breeding in goats can be efficiently obtained by the use of prostaglandins or progestagens combined with gonadotropins. Several estrus induction protocols are currently available with varying doses, duration, type and route of administration with progestagens, when applying gonadotrophins and using prostaglandins. The most common protocols used in small stock are progesterone (P4) slow-release intravaginal devices, prostaglandin and its analogue flurogestone acetate (FGA) (Freitas et al., 1996), norgestomet subcutaneous implants, daily oral MAP administrations (Goswami et al., 1998), medroxyprogesterone acetate (MPA) (Greyling and van der Nest, 2000) or daily intramuscular P4 administration (Patil et al., 2000). All these protocols have presented high percentage of animals in estrus, but the pregnancy rates obtained are lower than those following natural breeding.

Estrus synchronization in livestock focuses on the manipulation of either the luteal or the follicular phase of the estrus cycle. In does and ewes, the opportunity for control is greater during the luteal phase, which is of longer duration and more responsive to manipulation. Strategies can be employed to extend the luteal phase by supplying exogenous progesterone or to shorten this phase by prematurely regressing existing corpora luteal. The present study was designed to investigate the effect of prostaglandin on estrus synchronization and conception rate following Al with frozen semen after inducing estrus in Black Bengal doe.

\section{Materials and Methods}

The present study was conducted at the Artificial Insemination Center under the Department of Animal Breeding and Genetics, Bangladesh Agricultural University, Mymensingh, Bangladesh.

\section{Experimental animals}

Two trials were conducted involving twenty regular cyclic adult Black Bengal does. The does were selected from the breeding flock on the basis of the stage of the cycle. The age and body weight of the does were 18-21 months and 11-13 kg, respectively. The animals selected for the experiment were clinically examined for the general health. There were no conformational disorders or detectable defects that could influence the synchronization response.

\section{Management of the animal}

The animals were reared in the stall feeding system in USDA funded Black Bengal goat (BBG) project of Bangladesh Agricultural University. They were fed with Napier and/or German grass twice daily as per requirement. The feed was supplemented with mash type commercial concentrate (crude protein content: $120 \mathrm{~g} / \mathrm{kg} \mathrm{DM}$ and energy content: 10.4 MJ ME/kg DM) once in the morning and another in the afternoon at the rate of 120 $\mathrm{gm} / \mathrm{doe}$. The composition of the concentrate mixture with wheat bran $5.0 \mathrm{~kg}$, maize crust 
$3.0 \mathrm{~kg}$, mustard oil cake $2.0 \mathrm{~kg}$ and vitamin-mineral premix $100 \mathrm{gm}$ (for $10 \mathrm{~kg}$ mixture). They were allowed for grazing and exercise in a confinement area for 1 to 2 hours daily. Feeding regime was almost identical for all the goats under experimentation. Clean and safe water was made available at all times.

\section{Estrus synchronization method}

Synchronization of estrus was done by using synthetic $\mathrm{PGF}_{2 \alpha}$ analogue (Romano, 1998). At first the last date of showing estrus of all the does were recorded. Then a date was fixed on which all the does were in between days 5-17 of the cycle. On the schedule day each doe were given intramuscular injection of synthetic PGF $_{2 \alpha}$, Dinoprost ${ }^{\circledR}$ (a Prostaglandin $F_{2 \alpha}$ analogue, Techno Drugs, Bangladesh). Two doses of dinoprost ${ }^{\circledR}$ of 2 and $1 \mathrm{ml}$ were practiced. The treatments were given $2 \mathrm{ml}$ in 12 does $\left(1^{\text {st }}\right.$ trial) and $1 \mathrm{ml}$ in 8 does $\left(2^{\text {nd }}\right.$ trial). Thereafter, the does were observed closely up to 48 hours to record estrus behavior. The signs or behavior of synchronized estrus were recorded in detail. Most of the estrus behavior such as mount to other doe or let another doe mount her, frequent urination, mucus discharge from the vulva, swelling of vulva, tail flagging, nervousness, general attitude change, increased bleating, vocal activity, activity rate, circling, mock fighting, licking and rubbing each other, and feed intake are recorded in detail.

Does injected with $2 \mathrm{ml}$ dinoprost ${ }^{\circledR}$ were inseminated twice at 12 and 24 hours after inducing estrus, and those injected with $1 \mathrm{ml}$ dinoprost ${ }^{\circledR}$ were inseminated only 12 hours after inducing estrus. Because the duration of estrus of does treated with $2 \mathrm{ml}$ dinoprost ${ }^{\circledR}$ was 51 hours and does treated with $1 \mathrm{ml}$ dinoprost ${ }^{\circledR}$ was only 23 hours. The motility of semen was $55 \%$ and the concentration of semen was 100 million sperm per dose. In order to determine the conception rate all the does were observed to check whether they show next heat after artificial insemination. The does were checked again for the next 21 days to get correct information for conception. Estrus response; interval to estrus; duration of estrus (h) and pregnancy rate (\%) were recorded.

\section{Statistical analysis}

The data were analyzed and student's t-test was performed to compare the effect of treatments with the help of Statistical Package for Social Sciences 11.5 (SPSS Inc. 1999, Microsoft Corporation, 1998) windows package.

\section{Results and Discussion}

\section{Estrus symptoms}

The overall difference of signs of estrus between normal to synchronized estrus are shown in Table 1. Mount to other doe or let other doe mount her is a general estrus behavior (Fig. 1). This was a marked symptom in all dinoprost ${ }^{\circledR}$ treated does. There was no difference on mounting behavior between normal estrus and synchronized estrus. Frequent urination is another marked symptom of estrus but it was absent in dinoprost ${ }^{\circledR}$ treated does. Most does in estrus have a mucus discharge from the vulva. Mucus 
discharge was present in dinoprost ${ }^{\circledR}$ treated doe but the quantity was very low. The color of mucus was found transparent, but the viscosity was recorded thin and watery. Mucus discharge is very negligible in the doe treated with $2 \mathrm{ml}$ than $1 \mathrm{ml}$ treatment regime. Minor swelling of vulva was found in synchronized estrus. Tail flagging is a common phenomenon of the estrus and it was observed in synchronized doe (Fig. 1b). Sniffing of vulva (Fig. 1c) and rubbing each other (Fig. 1d) is found for synchronized group of doe. Other signs of estrus such as, nervousness, general attitude change, increased bleating, vocal activity, activity rate, circling, mock fighting, licking and rubbing each other, and feed intake were also noticed. The reason of absence of frequent urination, minor swelling of vulva and watery mucus discharge found in the present experiment is probably due to the quantity of synthetic prostaglandins, dose and individual response (Vierul et al., 1981).

Table 1. Behavioral signs of estrus in normal and synchronized estrus of Black Bengal does

\begin{tabular}{|c|c|c|}
\hline Traits & Normal estrus behavior & Synchronized estrus behavior \\
\hline $\begin{array}{l}\text { Mount another doe } \\
\text { or let another doe } \\
\text { mount her }\end{array}$ & $\begin{array}{l}\text { This trait was observed in all the } \\
\text { times during estrus }\end{array}$ & Initially higher but gradually decreased \\
\hline $\begin{array}{l}\text { Mucus discharge } \\
\text { from the vulva }\end{array}$ & $\begin{array}{l}\text { At the beginning of the cycle the } \\
\text { discharge is clear and stringy. The } \\
\text { color and consistency change } \\
\text { gradually throughout estrus to } \\
\text { become thick and white at the end }\end{array}$ & $\begin{array}{l}\text { Mucus discharge is present in Dinoprost }{ }^{\circledR} \\
\text { treated doe but the quantity is very little } \\
\text { than normal estrus. The color of mucus was } \\
\text { transparent, but the viscosity was thin and } \\
\text { watery }\end{array}$ \\
\hline Swelling of vulva & $\begin{array}{l}\text { Estrogen causes a generalized } \\
\text { swelling in the vulva lips. The vulva } \\
\text { may also appear to be from pink to } \\
\text { a reddish color due to an } \\
\text { increased blood supply and the } \\
\text { swelling }\end{array}$ & $\begin{array}{l}\text { Swelling of vulva was absent in dinoprost } \\
\text { treated doe }\end{array}$ \\
\hline Tail flagging & $\begin{array}{l}\text { Tail flagging has its own } \\
\text { characteristics. The tail quickly } \\
\text { waggles back and forth while it is } \\
\text { held at about a } 45 \text {-degree angle }\end{array}$ & $\begin{array}{l}\text { Tail flagging is initially higher ( } 1^{\text {st }} 6 \mathrm{hr} \text { ) but } \\
\text { gradually decreased }\end{array}$ \\
\hline Frequent urination & Present & Absent \\
\hline Nervousness & Does are all the times nervous & Does are all the times nervous \\
\hline $\begin{array}{l}\text { General attitude } \\
\text { change }\end{array}$ & Positive & Positive \\
\hline Increased bleating & Present & Present \\
\hline Vocal activity & Increased & Increased \\
\hline Activity rate & Increased & Increased \\
\hline Circling & Increased & Increased \\
\hline Mock fighting & It is also a common characteristic & $\begin{array}{l}\text { Mock fighting was observed in dinoprost } \\
\text { treated doe }\end{array}$ \\
\hline $\begin{array}{l}\text { Licking and rubbing } \\
\text { each other }\end{array}$ & Present & Present \\
\hline Feed intake & Gradually decreased & Not decreased \\
\hline
\end{tabular}



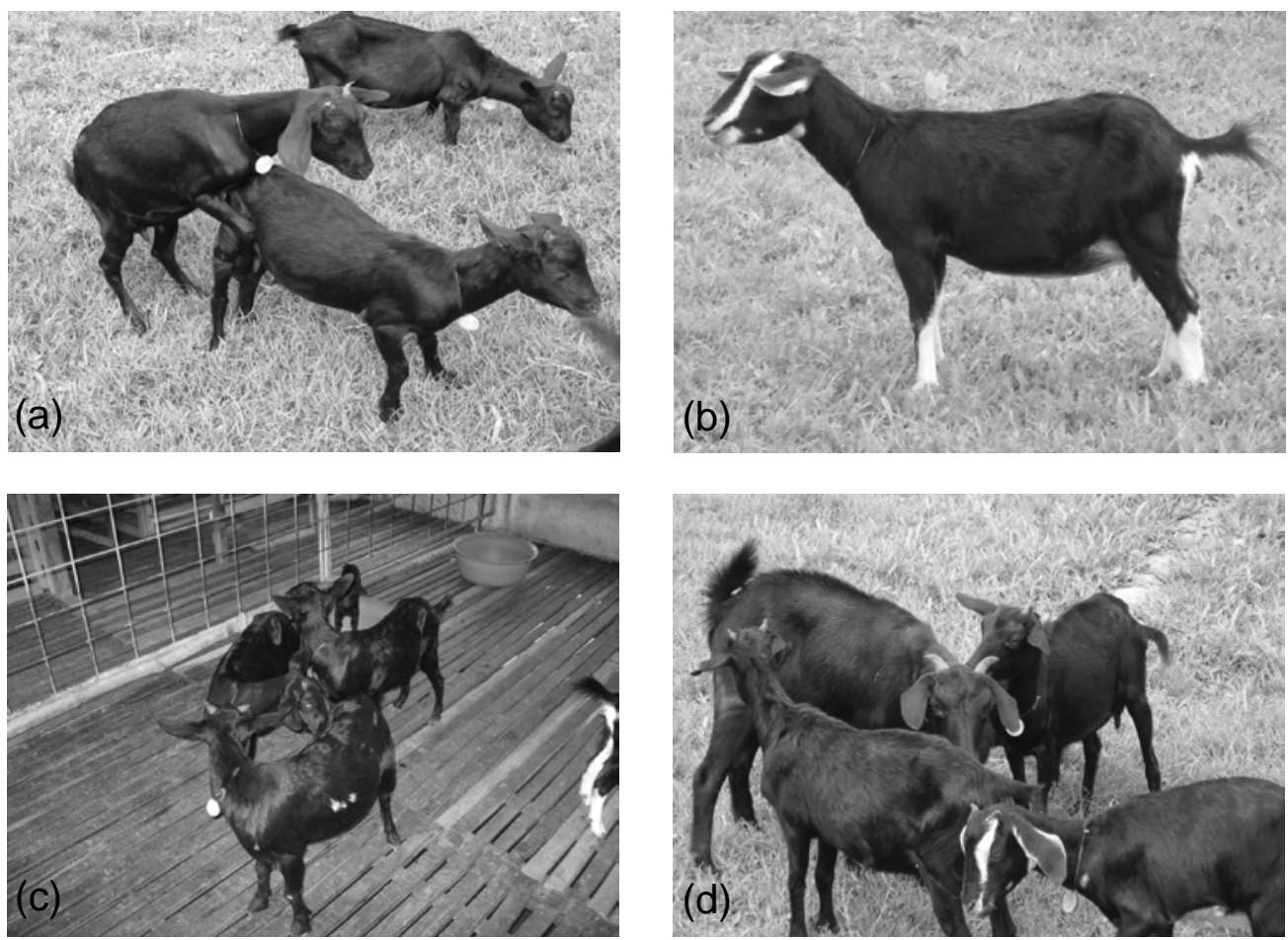

Fig. 1. Photograph showing estrus behavior in synchronized does (a) mounts to another doe or let another doe mount her, (b) tail flagging, (c) swelling of vulva and (d) rubbing each other

\section{Estrus response}

The effect of dinoprost ${ }^{\circledR}$ on estrus synchronization of Black Bengal goat is shown in Table 2. The occurrence of estrus was $87.5 \%$ and $100 \%$ when dose were treated with 2 $\mathrm{ml}$ and $1 \mathrm{ml}$ dinoprost ${ }^{\circledR}$, respectively. The interval to estrus was $45.5 \mathrm{hrs}$ in $2 \mathrm{ml}$ and $45.00 \mathrm{hrs}$ in $1 \mathrm{ml}$ treatment. The duration of estrus was $51.0 \mathrm{hr}$ and $23.0 \mathrm{hr}$ for does treated with $2 \mathrm{ml}$ and $1 \mathrm{ml}$, respectively. These differences were not reached in significant level and the variation might be due to the difference doses of dinoprost ${ }^{\circledR}$.

Prostaglandin have been shown to induce estrus in synchronized animals by regressing the active sensitive $C L$ by creating hypoxia within it and also by interfering the binding of LH hormone in the cell surface receptors (Nett et al., 1976; Wiltbank and Long, 1993). The quality and dose of the synthetic product of prostaglandin and time of hormone injection could affect the success of that product on estrus results and conception rate (Vierul et al., 1981; Jindal and Rattan, 1990)

From the result of the present study, it has been shown that the estrus response was $87.5 \%$ for treatment $2 \mathrm{ml}$ and $100 \%$ for treatment $1 \mathrm{ml}$. Other studies have shown

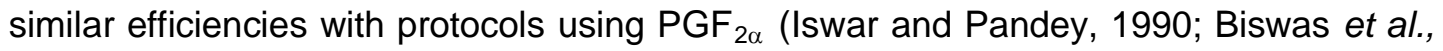
2000). Romano (1998) found that $100 \%$ does exhibit estrus after single doses of 62.5 $\mu \mathrm{g}$ and $125 \mu \mathrm{g}$ of Cloprostenol injection. Present result also is in agreement with Jindal 
and Rattan, (1990) and Brito et al. (2002) and they used cloprostenol for the synchronization of estrus in buffalo.

The time from injection to onset of estrus was $45.5 \mathrm{hr}$ and $45.0 \mathrm{hr}$ for $2 \mathrm{ml}$ and $1 \mathrm{ml}$ $\mathrm{PGF}_{2 \alpha}$ treated does, respectively. There was no difference observed between first and second treatment of Dinoprost ${ }^{\circledR}$ on the interval to estrus. Similar results were also observed in works using different synthetic prostaglandin, as cloprostenol (Brito et al., 2002). However, this result is consistent with some other work involves cloprostenol. (Romano, 1998) who found estrus at 46 to $48 \mathrm{hr}$ after cloprostenol injection. Ott et al. (1980) found that $94 \%$ of the treated does came into estrus within a mean of $53 \pm 3 \mathrm{hrs}$ after the second injection of $\mathrm{PGF}_{2 \alpha}$.

In the present research, the duration of estrus was $51 \mathrm{hr}$ and $23 \mathrm{hr}$ following $2 \mathrm{ml}$ and 1 $\mathrm{ml}$ injection of Dinoprost ${ }^{\circledR}$, respectively. This result is in agreement with Ishwar and Pundey (1992) who observed that the duration of estrus in synchronized doe varied between 24 to $40.87 \mathrm{hrs}$. However, in another study Biswas et al. (2000) reported that the duration of estrus varied between 35.005 to $38.675 \mathrm{hr}$. There were considerable variations in the duration of estrus in $1 \mathrm{ml}$ and $2 \mathrm{ml} \mathrm{PGF}_{2 \alpha}$ treated does. The difference between experiments on the duration of estrus is unknown. The quality of synthetic prostaglandins, dose, individual response or frequency of observation can have an effect on estrus response.

\section{Conception rate}

The number of does served and conceived following induced estrus is presented in Table 2. Between the treatments no significant difference was observed. The conception rate of estrus synchronized doe were $42.86 \%$ and $40.00 \%$ for treatment of 2 and $1 \mathrm{ml}$, respectively. The rate of conception recorded in this experiment was more or less similar to that of Ishwar and Puney (1990). However, the conception rate was lower than that of $75 \%$ conception rate in does treated with $125 \mu \mathrm{g}$ cloprostenol injection (Romano, 1998). On the contrary, the conception rate was higher than that of Akusu and Egbunake (1984), who observed $24-62 \%$ conception rate in maiden and pluriparous does, respectively.

Table 2. Effects of Dinoprost ${ }^{\circledR}$ on estrus synchronization in Black Bengal dose

\begin{tabular}{|c|c|c|c|c|c|c|}
\hline Treatment & Doses & $\begin{array}{c}\text { Total no. of } \\
\text { doe }\end{array}$ & $\begin{array}{c}\text { Estrus } \\
\text { response (\%) }\end{array}$ & $\begin{array}{c}\text { Interval to } \\
\text { estrus (hr) }\end{array}$ & $\begin{array}{c}\text { Duration of } \\
\text { estrus (hr) }\end{array}$ & $\begin{array}{c}\text { Conception } \\
\text { Rate }^{\star} \text { (\%) }\end{array}$ \\
\hline 1 & $2 \mathrm{ml}$ & 12 & 87.50 & 45.50 & 51 & 42.86 \\
2 & $1 \mathrm{ml}$ & 8 & 100.00 & 45.00 & 23 & 40.00 \\
\hline
\end{tabular}

*t-test was performed to compare the treatments of Dinoprost ${ }^{\circledR}$ on the performance

\section{Conclusion}

The results of this study indicated that the estrus respense was observed higher in $1 \mathrm{ml}$ dinoprost $^{\circledR}$ treated does compared with $2 \mathrm{ml}$ treated does. From the result of this study it 
can be concluded that synchronization of estrus with dinoprost ${ }^{\circledR}$, a synthetic analogue of $1 \mathrm{ml} /$ does $\mathrm{PGF}_{2 \alpha}$ may be suitable for estrus synchronization of Black Bengal goat. However, extended systematic research is essential for more refinement of the findings.

\section{Acknowledgements}

Major funding for the research fund has been provided through a grant form the United States Department of Agriculture (USDA), foreign agriculture service and is gratefully acknowledged.

\section{Literature Cited}

Akusu, M. O. and Egbunike, G. N. 1984. Fertility of the West African dwarf goat in its native environment following $\mathrm{PGF}_{2 \alpha}$ induced estrus. Vet Q. 6: 173-76.

Amin, M. R., Husain, S. S. and Islam, A. B. M. M. 2000. Evaluation of Black Bengal goats and their cross with Jamnapari breed for carcass characteristics. Small. Rumin. Res. 38: 211-215.

Biswas, S., Ghosh, B. B., Bandyopadhyay, S. K., Roy, M. M. and Senapati, P. K. 2000. Response of Buserelin $(\mathrm{GnRH})$ on synchronization of estrus and multiovulation in Black Bengal goat treated with PMSG and PGF $2 \alpha$. Journal-of-Interacademicia. 4: 290-293.

Brito, L. F. C., Satrapa, R. and Marson, E. P. 2002. Efficacy of PGF $_{2 \alpha}$ to synchronize estrus in water buffalo cows. J. Animal. Reprod. Sci. 73: 23-35.

Freitas, V. J. F., Bosc, M. and Saumande, J. 1996. Induction and synchronization of estrus in goats: the relative efficiency of one versus two fluorogestone acetate-impregnated vaginal sponges. Theriogenology. 45: 1251-1256.

Goswami, J., Sarmah, B. C., Chakaravarty, P., Sarmah, B. K. and Goswami, R. N. 1998. Follicular growth in response to exogenous gonadotrophin in anestrus goat. Ind. Vet. J. 75: 311-313.

Greyling, J. P. C. and Van der Nest, M. 2000. Synchronization of estrus in goats: dose effect of progesterone. Small. Rumin. Res. 1: 36:201-207.

Husain, S. S. 1993. A study on the productive performance and genetic potentials of Black Bengal goats. PhD. thesis. Department of Animal Breeding and Genetics, Bangladesh Agricultural University, Mymensingh. pp. 45-63.

Ishwar, A. K. and Pandey, J. N. 1990. Estrus synchronization and fertility behavior in Black Bengal goats following either progesterone or prostaglandin treatment. Theriogenology. 34: 1015-24.

Ishwar, A. K. and Pandey, J. N. 1992. Estrus synchronization and fertiliting in Black Bengal goats following administration of progesterone/prostaglandin and gonadotropins. J. Vet. Sci. 52: 141-146.

Jindal, R. G. and Rattan, P. J. S. 1990. Influence of estrus synchronization on the hormonal and biochemical status of blood in buffaloes. In: Proceed. Second world buffalo cong. (New Delhi), 3, 121-130.

Lauderdale, J. W., McAllister, J. F., Kartzer, D. D. and Moody, E. L. 1981. Use of PGF $2 \alpha$ in cattle breeding. Acta Vet. Scand. 77: 181-191.

Nett, T. M., McClellan, M. A. and Niswender, G. D. 1976. Effects of prostaglandins on the Corpus Luteum, blood flow, secretion of progesterone and morphology. J. Bio. Repro. 15: 66-78. 
Bang. J. Anim. Sci. 2009, 38(1\&2)

Ott, R. S., Nelson, D. R., and Hixon, J. E. 1980. Fertily of goats following synchronization of estrus with PGF $2 \alpha$. Theriogenology. 13: 341-50.

Patil, A. D., kurse, B. P., Phalak, K. R. and Dhoble, R. L. 2000. Synchronization of estrus using progesterone and PMSG in Osmanabadi goats. Ind. J. Anim. Sci. 70: 281-282.

Peters, A. R. 1983. Some indigenous hormonal therapy in the cow. Vet. practice, England, $5^{\text {th }}$ March. pp. 19-110.

Romano, J. E. 1998. Effect of two doses of cloprostenol in two schemes for estrous synchronization in Nubian does. Small. Rumin. Res. 28: 171-176.

SPSS, Windows for version-11.5. Release on 27.10.1999 (Microsoft Corp. 1998). Trends SPSS Inc., Michigan Avenue, Chicago, IL. 19-182.

Vierul, T. F., Boland, M. P. and Gordon, L. 1981. Effect of progesterone treatments on incidence of estrus and pregnancy rates in ewes. Anim. Reprod. Sci. 24: 109-118.

Wiltbank, C. V. and Long, S. E. (1993). The effect of superovulation on the chromosome complement of early embryos. Proc. $4^{\text {th }}$ Eur. Collog. Cytogenetis. Domestic. Anim. Uppsala. 168-171. 